\title{
Kulturna potrošnja, društvene nejednakosti i regionalne razlike: istraživanje Eurobarometra u Hrvatskoj 2013. godine
}

\section{Željka Tonković}

Sveučilište u Zadru, Odjel za sociologiju, Hrvatska e-mail:ztonkovi@unizd.hr

\section{Sven Marcelić}

Sveučilište u Zadru, Odjel za sociologiju, Hrvatska e-mail:smarceli@unizd.hr

\section{Krešimir Krolo}

Sveučilište u Zadru, Odjel za sociologiju, Hrvatska e-mail:kkrolo@unizd.hr

SAŽETAK Cilj ovog članka jest ustanoviti postoji li povezanost između kulturne potrošnje, društvene nejednakosti i regionalnih razlika u Hrvatskoj na osnovi podataka prikupljenih istraživanjem Eurobarometra iz 2013. godine. U uvodnom dijelu rada izloženi su različiti teorijski pristupi kulturnoj potrošnji s ciljem preciznijeg objašnjavanja odrednica kulturne potrošnje uzimajući u obzir složenost tranzicijskih i posttranzicijskih specifičnosti hrvatskoga društva. Metodološko-empirijski dio rada podijeljen je u tri koraka. Prvo se faktorskom analizom kulturna potrošnja ispitanika $(\mathrm{N}=787)$ grupirala u dva temeljna skupa, javnu i privatnu kulturnu potrošnju, a na temelju čega su se kreirali njihovi agregatni indeksi. Drugi je korak uključivao hijerarhijsku regresijsku analizu kako bi se ustanovila prediktivnost socioekonomskih korelata u objašnjavanju razlika u tipovima kulturne potrošnje. Treći je korak uključivao usporedbu indeksa kulturne potrošnje među regijama u Hrvatskoj, uzimajući pritom u obzir indekse njihove razvijenosti. Rezultati provedenih analiza upućuju na statistički značajnu povezanost između indeksa kulturne potrošnje s više indikatora socioekonomskog statusa te s obrazovnim postignućem, spolom i rezidencijalnim statusom. Značajne razlike utvrđene su i između hrvatskih regija, pri čemu su Zagreb i okolica te Rijeka i Gorski kotar jedine regije s iznadprosječnim vrijednostima na indeksima kulturne potrošnje, te se može zaključiti da je kulturna potrošnja snažno vezana uz ukupnu razvijenost nekog prostora.

Ključne riječi: kulturna potrošnja, društvene nejednakosti, regionalne razlike, Eurobarometar, Hrvatska, socioekonomski status. 


\section{Uvod}

\subsection{Teorijsko polazište rada}

Odnos između društvene stratifikacije i kulturne potrošnje predstavlja temu koja još od sedamdesetih godina prošlog stoljeća nastavlja inspirirati veliki broj znanstvenih radova. Rastući broj recentnih istraživanja te tematike doprinosi ne samo dubljem razumijevanju društvenih nejednakosti u kulturnoj potrošnji nego i društvenih nejednakosti općenito. U suvremenim raspravama u tom području mogu se, prema Chanu i Goldthorpeu (2010.), razlikovati tri temeljna teorijska pristupa. Prvi pristup zasniva se na tezi o homologiji između sustava kulturnih i društvenih hijerarhija, a svoje najsnažnije teorijsko uporište temelji na kapitalnom djelu Pierrea Bourdieua (2011. [1979.]) Distinkcija: društvena kritika suđenja. S tog motrišta, društveno priznatoj hijerarhiji umjetnosti i umjetničkih djela odgovara društvena hijerarhija potrošača, pri čemu kulturni ukus djeluje kao označitelj klase i klasnih distinkcija. Razlike u društvenom podrijetlu i školskom postignuću među pripadnicima različitih društvenih klasa rezultiraju različitim obrascima kulturnog ukusa i potrošnje, kao i drugim životnostilskim odrednicama (npr. uređenje doma, prehrana, odijevanje). Pripadnici dominantnih klasa pritom koriste vlastiti kulturni kapital, u njegovom utjelovljenom, objektiviranom i institucionaliziranom obliku, kako bi iskazali superiornost vlastitog životnog stila i zadržali privilegirani položaj u sustavu društvenih razlika.

Premda je teorija homologije ostala jednim od temeljnih polazišta sociološkog promišljanja društvene stratificiranosti kulturne potrošnje, već od osamdesetih, a osobito od devedesetih godina dvadesetog stoljeća, oblikovala su se dva suprotstavljena pristupa. Prvi od njih, koji Chan i Goldthorpe (2010.) nazivaju teorijom individualizacije, ukazuje na opadanje važnosti klasnih i statusnih hijerarhija u društvima „Visoke“ ili „kasne“ modernosti (Giddens, 1990.; 1991.), pri čemu klasne distinkcije blijede, a društvene se razlike i nejednakosti individualiziraju. Klasno specifične biografije zamjenjuju „refleksivne“ biografije i novi životni stilovi (Beck, 1992.), kulturni se ukusi fragmentiraju, a potrošači se moraju oslanjati na vlastite kulturne kompetencije i „estetsku refleksivnost“ (Lash, 1993.) kako bi refleksivno gradili vlastiti potrošački i životni stil. U tom kontekstu sama se potrošnja, pa i kulturna potrošnja, primarno shvaća kao složen postupak identificiranja, dekodiranja i selekcije znakova (Shields, 1992.).

Za razliku od teorija individualizacije, drugi utjecajni teorijski pristup koji se suprotstavlja teoriji homologije, teorija omnivora (svejeda) i univora (jednojeda), ne zastupa motrište o gubljenju jasne korespondencije između društvenih i kulturnih hijerarhija (Chan i Goldthorpe, 2010.). Umjesto toga ta se teorija temelji na tezi da se razlike u obrascima kulturnih preferencija i potrošnje u suvremenim društvima ne zasnivaju na isključivoj opreci „legitimnog“ i „popularnog“ ukusa, odnosno highbrow (visoke) i lowbrow (niske) kulture, već na razlikama između kulturnih omnivora i univora. Istraživanja koja se temelje na tome pristupu pokazuju da pripadnici viših društvenih slojeva iskazuju preferencije prema širokom rasponu kulturnih sa- 
držaja koji osim legitimnih djela visoke kulture uključuju i selekciju žanrova i djela koja se ubrajaju u popularnu kulturu. To se teorijsko polazište najviše vezuje uz djelo američkog teoretičara Richarda Petersona (Peterson, 1992.; Peterson i Simkus, 1992.; Peterson i Kern, 1996.).

Pored prethodno izloženih razlika u teorijskim polazištima, suvremena istraživanja u tom području mogu se razlikovati i s obzirom na načine na koje se konceptualiziraju i operacionaliziraju temeljni agensi društvene stratifikacije: klasa i status (Chan i Goldthorpe, 2010.). Naime, kako primjećuju ti autori, pojmovi klase i statusa nerijetko se smatraju međusobno zamjenjivima ili analitički neodvojivima, što smatraju pogrešnim. Polazeći od veberijanske distinkcije između klase i statusa, Chan i Goldthorpe klasu definiraju kao položaj u proizvodnim odnosima. S druge strane, koncept društvenog statusa povezuju s hijerarhijom profesija, koja odražava razlike u društvenom ugledu, ali i u razinama obrazovanja i visini prihoda koji se povezuju s različitim profesijama i profesionalnim skupinama. Rezultati istraživanja koja polaze od navedene distinkcije između klase i statusa upućuju na zaključak da u stratifikaciji kulturne potrošnje važniju ulogu ima društveni status od klase (Chan i Goldthorpe, 2005., 2006.; Bukodi, 2010.; Coulangeon i Lemel, 2010.).

\subsection{Pregled prethodnih istraživanja}

Istraživanje Eurobarometra važno je za proučavanje kulturne potrošnje u zemljama postsocijalističke Europe, s obzirom na to da omogućuje komparativno promatranje u odnosu na „stare“ zemlje članice Europske unije. Naime većina teorijskih pristupa i istraživanja unutar toga predmetnog područja odnosi se na društva zapadnog kapitalizma, dok su slična istraživanja u postsocijalističkim društvima razmjerno malobrojna. Recentna komparativna istraživanja sugeriraju da je utjecaj obrazovanja i socioprofesionalnog statusa na razinu sudjelovanja u kulturnoj potrošnji veći u postsocijalističkim društvima Srednje i Istočne Europe nego u visokorazvijenim europskim društvima (Gerhards i sur., 2013.; van Hek i Kraaykamp, 2013.). S druge strane, kada je riječ o kulturnoj potrošnji u Hrvatskoj i drugim zemljama bivše Jugoslavije, pokazuje se da razlike u ekonomskom statusu, odnosno visini prihoda i ekonomskom kapitalu nemaju značajniji utjecaj na kulturno pozicioniranje. Primjerice, istraživanja kulturnih praksi u Srbiji i Makedoniji pokazuju da je utjecaj prihoda, odnosno ekonomskog kapitala na formiranje kulturnog ukusa i obrazaca kulturne potrošnje manje značajan od obrazovnog postignuća, dobi i rezidencijalnog statusa (Cvetičanin, 2007.; Cvetičanin, Nedeljković i Krstić, 2012.; Spasić, 2013.). ${ }^{1}$

1 Iako Srbija i Makedonija nisu članice Europske unije i nisu obuhvaćene Eurobarometrom, njihovo je iskustvo komparativno važno s obzirom na zajednički državni okvir u prošlosti, koji omogućuje da se sagledaju posljedice tranzicije nakon formiranja nacionalnih kulturnih konteksta. 
Premda je problem nejednake dostupnosti kulturnih sadržaja i mogućnosti participacije u kulturnom životu s obzirom na ekonomske i druge prepreke prepoznat još u ključnim dokumentima nacionalne kulturne politike početkom dvijetisućitih (Cvjetičanin i Katunarić, 1999.; Cvjetičanin i Katunarić, 2003.), pitanje pristupa kulturi ostalo je prilično zanemareno te izostaju eksplicitne mjere usmjerene na uklanjanje prepreka pristupu kulturnim sadržajima (Primorac, Obuljen Koržinek i Uzelac, 2015.). Također, izostaju sustavnija istraživanja kulturne potrošnje i ukusa na reprezentativnom nacionalnom uzorku kojima bi se ispitala potražnja za različitim tipovima kulturnih sadržaja (Primorac i sur., 2015.). Unatoč tomu iz prethodnih istraŽivanja kulturne potrošnje i životnih stilova mladih (Ilišin i Radin, 2007.; Zdravković, 2014.; Tonković, Krolo i Marcelić, 2014.; Marcelić, Krolo i Tonković, 2015.) mogu se izdvojiti neke socioekonomske odrednice kulturne potrošnje. Ponajprije, prethodna istraživanja upućuju na postojanje distinkcija između tradicionalnih i elitnih obrazaca kulturne potrošnje (Ilišin i Radin, 2007.; Zdravković, 2014.; Tonković i sur., 2014.) koje se mogu povezati s Bourdieuovom teorijom, koja ukazuje na stabilnost distinkcija između legitimnog i popularnog ukusa. Kada je riječ o obrascima potrošnje visoke kulture, može se zaključiti da su oni manje zastupljeni u populaciji u usporedbi s tradicionalnim i komercijalnim obrascima kulturne potrošnje, ali ih zato odlikuju stabilnije karakteristike koje se povezuju s visokoobrazovanim roditeljima i odrastanjem u urbanim sredinama. ${ }^{2}$

Osim utjecaja statusa i klase, prethodna istraživanja (Gerhards, Hans i Mutz, 2013.; Kraaykamp, van Eijck i Ultee, 2010.; López Sintas i García Álvarez, 2002.) uputila su na povezanost rezidencijalnog statusa, odnosno razine urbaniziranosti mjesta i razvijenosti regije stanovanja s učestalošću posjećivanja kulturnih sadržaja. U regijama s većom gustoćom kulturnih sadržaja te u ekonomski razvijenim regijama kulturna je potrošnja redovito veća jer se češće radi o urbaniziranim prostorima koji imaju bolju kulturnu infrastrukturu, što se pokazuje u istraživanjima u nizu zemalja različitih ekonomskih, političkih i historijskih statusa, od razvijenih zapadnih demokracija preko posttranzicijskih zemalja do zemalja Latinske Amerike (Chan, 2010.:239; Cavallaro, 2014.:104-107). Prema tome, premda i stanovnici ruralnih naselja i slabije razvijenih regija mogu iskazivati kulturne preferencije za sadržaje visoke kulture, njima će oni biti teže dostupni zbog čega će i učestalost participacije biti niža. Drugim riječima, može se zaključiti da razlike u kulturnoj potrošnji proizlaze ne samo iz individualnih razlika u „estetskoj kompetenciji“ (Bourdieu, 2011.) nego i iz nejednakih mogućnosti sudjelovanja u kulturnim sadržajima uslijed njihove nedostupnosti.

Ovaj se rad temelji na analizi rezultata istraživanja Eurobarometer 79.2., provedenom u travnju i svibnju 2013. godine u okviru omnibus istraživanja na reprezentativnom uzorku građana starijih od 15 godina. Istraživanje je obuhvatilo svih 27 zemalja članica Europske unije i Hrvatsku, koja u vrijeme provedbe istraživanja nije

2 Premda se ne bave kulturnom potrošnjom u užem smislu, u hrvatskoj sociologiji valja istaknuti nekoliko radova koji tematiziraju različite aspekte potrošnje i potrošačkih praksi (Hromadžić, 2008.; Čolić, 2008.; Burić, 2010.). 
bila članicom Unije. S obzirom na relevantnost geografske komponente kulturne potrošnje, u radu će se konzultirati i pokazatelji kao što su vrijednosti hrvatskog indeksa razvijenosti te ulaganja u kulturu na razini županija. U analizi podataka polazi se od sljedećih istraživačkih pitanja: (1) u kojoj su mjeri razlike u kulturnoj potrošnji povezane sa sociodemografskim i socioekonomskim indikatorima, (2) u kojoj su mjeri razlike u kulturnoj potrošnji povezane s veličinom naselja i regijom stanovanja.

\section{Istraživanje Eurobarometra o kulturnoj potrošnji}

\subsection{Uzorak i postupak}

U prikupljanju podataka u svim je državama primijenjen višeetapni probabilistički uzorak, a broj točaka uzorkovanja određen je proporcionalno veličini populacije i gustoći naseljenosti. Točke uzorkovanja određene su na način da uzorak bude reprezentativan s obzirom na administrativne regionalne jedinice (Zagreb i okolica; Sjeverna Hrvatska; Slavonija; Lika i Banovina; Istra, Rijeka i Gorski kotar; Dalmacija) i veličinu naselja (podijeljenih u četiri skupine: do 2000 stanovnika, od 2000 do 10.000, od 10.000 do 100.000 te preko 100.000 stanovnika). Unutar svake od točaka uzorkovanja odabrane su početne adrese od kojih je kretao daljnji izbor kućanstava, metodom random route. Prikupljanje podataka izvršeno je metodom osobnog intervjua, pri čemu su ispitanici u odabranim kućanstvima birani slučajno, prema pravilu posljednjeg rođendana (Eurostat, 2013.).

U Hrvatskoj je ukupno sudjelovalo 1000 ispitanika. Za potrebe rada iz analize su izostavljeni ispitanici stariji od 65 godina, a koji su činili 21,3\% uzorka $(\mathrm{N}=787) .{ }^{3} \mathrm{U}$ tablici 1. prikazana je struktura uzorka prema sociodemografskim obilježjima spola, dobi, dobi u kojoj je završeno redovno školovanje, regiji stanovanja i veličini naselja. U uzorku su nešto zastupljenije žene od muškaraca (59,6\%). Najveći udio ispitanika $(56,9 \%)$ završio je redovno školovanje u dobi od 16 do 19 godina, te se može zaključiti da je riječ o ispitanicima sa srednjoškolskom naobrazbom. Najviše ispitanika dolazi iz naselja koja imaju do 2000 stanovnika (40,2\%).

3 Razlog za takvu odluku leži u činjenici da je uzorak starijih od 65 upitan s nekoliko osnova. Prvenstveno, omjer žena i muškaraca viši je od 2:1, dok je u ostalim dobnim skupinama taj nesrazmjer znatno manji i ne prelazi 1,4:1. Sastav tog uzorka također je znatno obrazovaniji od prosjeka iste populacije. Drugim riječima, rezultati bi pretežno odražavali stavove obrazovanijih starijih žena. 
Tablica 1.

Struktura uzorka

\begin{tabular}{|c|c|c|c|}
\hline & & $N$ & $\%$ \\
\hline \multirow[t]{2}{*}{ spol } & muški & 318 & 40,4 \\
\hline & ženski & 469 & 59,6 \\
\hline \multirow[t]{4}{*}{ dob } & od 15 do 24 & 106 & 13,5 \\
\hline & od 25 do 39 & 248 & 31,5 \\
\hline & od 40 do 54 & 245 & 31,1 \\
\hline & od 55 do 65 & 188 & 23,9 \\
\hline \multirow{6}{*}{$\begin{array}{l}\text { dob u kojoj je završeno redovno } \\
\text { obrazovanje }\end{array}$} & do 15 godina & 77 & 9,8 \\
\hline & do 16 do 19 godina & 448 & 56,9 \\
\hline & 20 i više & 170 & 21,6 \\
\hline & još se školuju & 72 & 9,1 \\
\hline & bez obrazovanja & 4 & 0,5 \\
\hline & bez odgovora & 16 & 2,1 \\
\hline \multirow[t]{6}{*}{ regija } & Zagreb i okolica & 200 & 25,4 \\
\hline & Sjeverna Hrvatska & 136 & 17,3 \\
\hline & Slavonija & 134 & 17,0 \\
\hline & Lika i Banovina & 67 & 8,5 \\
\hline & Istra, Rijeka i Gorski kotar & 86 & 10,9 \\
\hline & Dalmacija & 164 & 20,8 \\
\hline \multirow[t]{4}{*}{ veličina naselja } & do 2000 stanovnika & 316 & 40,2 \\
\hline & $2001-10.000$ stanovnika & 125 & 15,9 \\
\hline & $10.001-100.000$ stanovnika & 157 & 19,9 \\
\hline & više od 100.000 stanovnika & 189 & 24,0 \\
\hline \multirow{3}{*}{$\begin{array}{l}\text { socioekonomski status } \\
\text { (samoprocjena) }\end{array}$} & niži & 214 & 27,4 \\
\hline & srednji & 420 & 53,7 \\
\hline & visoki & 148 & 18,9 \\
\hline \multirow[t]{5}{*}{ socioprofesionalni status } & niži & 114 & 15,9 \\
\hline & srednji & 151 & 21,1 \\
\hline & viši & 92 & 11,7 \\
\hline & umirovljenici & 135 & 17,2 \\
\hline & nezaposleni & 223 & 28,3 \\
\hline
\end{tabular}

\subsection{Pregled instrumenata}

\section{Kulturna potrošnja}

Dio upitnika koji se odnosio na kulturnu potrošnju sadržavao je pitanja o učestalosti posjećivanja različitih kulturnih sadržaja u posljednjih godinu dana, o bavljenju kulturnim i umjetničkim aktivnostima te o korištenju interneta u kulturne svrhe. Kulturna potrošnja u Eurobarometrovom istraživanju bila je operacionalizirana kao učestalost posjećivanja i konzumacije devet različitih kulturnih sadržaja. Ispitanicima 
je pritom bila ponuđena skala s četirima stupnjevima učestalosti $(1=$ nijednom, $2=$ $1-2$ puta, $3=3-5$ puta, $4=$ više od 5 puta).

Slika 1.

Razina sudjelovanja u kulturnoj potrošnji (\% najmanje jednom godišnje): usporedba Hrvatske i EU 27

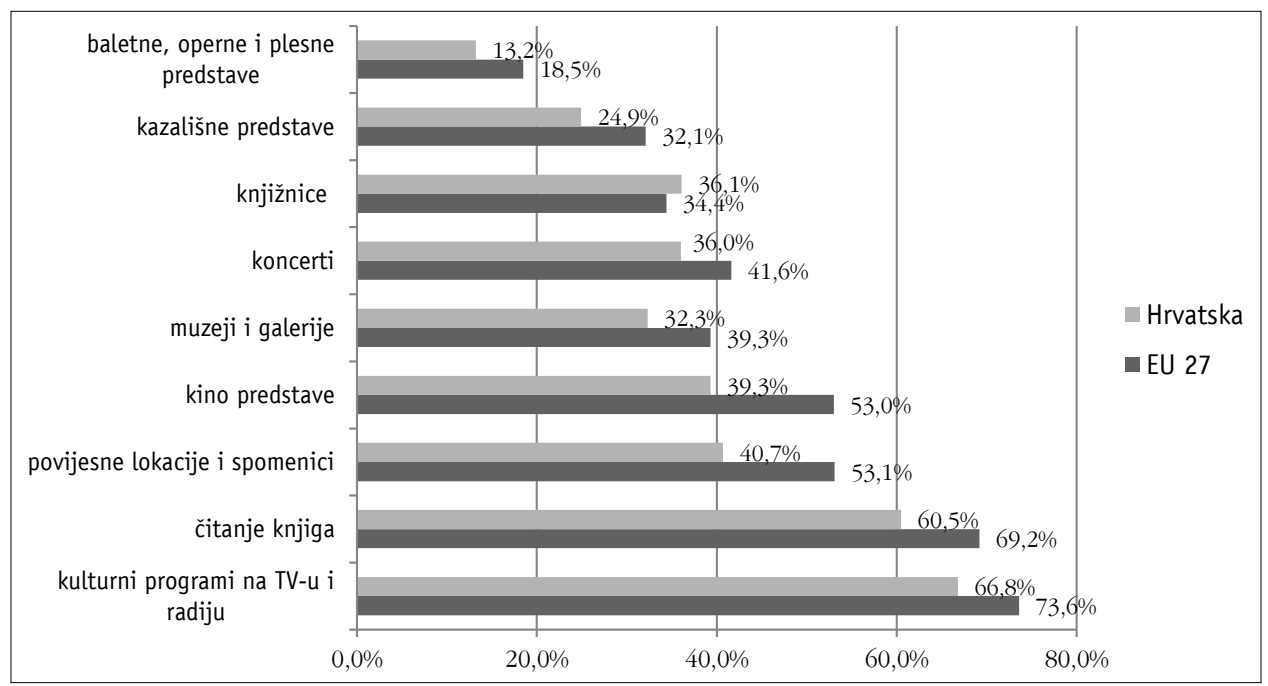

Izvor: izračun autora prema Eurostat, 2013.

Rezultati istraživanja pokazuju da je razina sudjelovanja u kulturnoj potrošnji u populaciji u Hrvatskoj manja od prosjeka za EU 27. ${ }^{4}$ Razlike između hrvatskog prosjeka i prosjeka EU 27 najveće su kod učestalosti odlazaka na kino predstave (39,3\% u usporedbi s 53\%), obilazaka povijesnih spomenika i sličnih lokacija (40,7\% u usporedbi s 53,1\%) i čitanja knjiga (60,5\% u usporedbi s 69,2\%). Iz slike 1 također se može primijetiti da je postotak ispitanika koji su unutar godine dana najmanje jednom posjetili neki od sadržaja visoke kulture (npr. muzej, kazalište, opera) u hrvatskom uzorku manji nego u prosjeku Europske unije, po čemu se Hrvatska može usporediti sa zemljama europskog juga (Grčka, Cipar, Portugal) i Istočnom Europom (Rumunjska, Bugarska, Poljska) (Eurostat, 2013.).

Ovdje valja napomenuti da je prvo istraživanje Eurobarometra o kulturnoj potrošnji provedeno 2007. godine te je jedna od intencija Europske komisije kao naručitelja istraživanja bila ispitati utjecaj ekonomske krize i posljedičnog smanjenja platežne moći građana na kulturnu potrošnju i participaciju (Eurostat, 2013.). Usporedba dobivenih rezultata iz prvog i drugog vala istraživanja upućuje na blago opadanje kulturne potrošnje na razini prosjeka Europske unije, ali je to opadanje znatno izraženije u zemljama Srednje i Istočne Europe (npr. Mađarska, Rumunjska) te u zemljama koje je financijska i ekonomska kriza 2008. godine više pogodila (npr. Grčka). S obzirom da Hrvatska nije bila uključena u prvom valu istraživanja, ne-

${ }^{4}$ Podaci se odnose na ispitanike u dobi od 15 do 65 godina. 
moguće je donositi slične zaključke o kretanju kulturne potrošnje prije i poslije ekonomske krize.

Kako bi se utvrdila struktura kulturne potrošnje, korištena je eksplorativna faktorska analiza metodom glavnih komponenti uz ortogonalnu varimax rotaciju. U svrhu definiranja broja faktora korišten je Kaiser-Guttmanov kriterij ekstrakcije faktora, prema kojem se zadržavaju oni faktori koje imaju svojstvene vrijednosti jednake ili veće od 1,0 te Cattellov Scree test. Izlučena su dva faktora koja zajedno objašnjavaju 58,31\% varijance (tablica 2.). Prvi dobiveni faktor, koji objašnjava 46,65\% varijance, zasićen je sa šest varijabli: posjećivanje kazališnih predstava; posjećivanje koncerata; posjećivanje baletnih, opernih ili plesnih predstava; odlasci u kino; posjećivanje muzeja i galerija; obilazak povijesnih spomenika. S obzirom da taj faktor upućuje na tendenciju ispitanika da posjećuju različite tipove javnih kulturnih sadržaja, faktor smo nazvali javna kulturna potrošnja. Drugi dobiveni faktor obuhvaća tri varijable: praćenje kulturnih programa na televiziji ili radiju, čitanje knjiga, posjećivanje knjižnica. Kako je riječ o faktoru koji primarno opisuje interes za konzumaciju kulturnih sadržaja u privatnom prostoru (npr. knjige, televizijski i radio programi), faktor je nazvan privatna kulturna potrošnja.

Tablica 2.

Kulturna potrošnja: matrica faktora nakon provedene varimax transformacije

\begin{tabular}{|l|c|c|}
\hline & Javna kulturna potrošnja & Privatna kulturna potrošnja \\
\hline kazališne predstave & 0,777 & \\
\hline koncerti & 0,738 & \\
\hline baletne, operne ili plesne predstave & 0,712 & \\
\hline kino predstave & 0,681 & \\
\hline muzeji i galerije & 0,673 & \\
\hline povijesni spomenici & 0,568 & \\
\hline čitanje knjiga & & 0,780 \\
\hline kulturni programi na TV-u/radiju & & 0,758 \\
\hline knjižnice & & 0,672 \\
\hline
\end{tabular}

Na temelju ekstrahiranih faktora konstruirana su dva indeksa: indeks javne kulturne potrošnje $(\mathrm{M}=8,96 ; \mathrm{SD}=3,61$; raspon $6-24$; Cronbachov $\alpha=0,836)$ i indeks privatne kulturne potrošnje ( $\mathrm{M}=6,61 ; \mathrm{SD}=2,89$; raspon $3-12$; Cronbachov $\alpha=0,687)$. Indeksi predstavljaju agregatne rezultate na ukupno šest (javna potrošnja), odnosno tri varijable (privatna potrošnja). Pojedini rezultat na indeksu pritom prvenstveno odražava učestalost konzumacije kulturnih sadržaja, ali i njihovu raznolikost. Uvid u distribuciju frekvencija pokazuje da 35,4\% ispitanika nije nijednom u posljednjih godinu dana konzumiralo kulturne sadržaje koji se ovdje ubrajaju u javnu kulturnu potrošnju, dok je taj postotak za privatnu kulturnu potrošnju niži i iznosi 22,5\%. 


\subsection{Indikatori socioekonomskog statusa}

\section{Indeks posjedovanja materijalnih dobara}

Upitnik nije sadržavao pitanje o prihodima kao izravnom pokazatelju ekonomskog kapitala, ali je sadržavao pitanje o strukturi posjedovanja materijalnih dobara u kućanstvu, uključujući tehničku i audiovizualnu opremu (npr. televizor, osobno računalo, DVD player). Kreiran je indeks posjedovanja materijalnih dobara, koji predstavlja agregatni rezultat na ukupno sedam čestica $(M=4,64 ; \mathrm{SD}=1,94$; raspon $0-7$; Cronbachov $\alpha=0,728){ }^{5}$

Tablica 3.

Posjedovanje materijalnih dobara

\begin{tabular}{|l|c|}
\hline & Da (\%) \\
\hline televizor & 98,1 \\
\hline stan/kuća (otplaćeno) & 73,4 \\
\hline automobil & 67,2 \\
\hline osobno računalo & 60,9 \\
\hline pristup internetu & 60,6 \\
\hline DVD player & 54,4 \\
\hline glazbeni CD player & 37,3 \\
\hline Indeks posjedovanja materijalnih dobara ${ }^{*}$ & $\mathrm{M}=4,94 ; \mathrm{SD}=1,80$ \\
\hline
\end{tabular}

*Cronbachov $\alpha=0,728$

\section{Samoprocjena društvenog statusa}

Koristeći skalu od 1 do 10 sudionici istraživanja trebali su procijeniti vlastiti status u društvu, odnosno odgovarajuću razinu koju zauzimaju u društvenoj hijerarhiji. Za potrebe daljnjih analiza ispitanici su podijeljeni u tri skupine: niži $(1-4)$, srednji $(5-6)$ i viši $(7$ - 10). Distribucija samoprocijenjenog društvenog statusa pokazuje da je najveći udio ispitanika $(53,4 \%)$ vlastiti status procijenio srednjim, 27,2\% nižim, a 18,8\% višim.

\section{Socioprofesionalni status}

Varijabla socioprofesionalnog statusa kreirana je na temelju odgovora sudionika istraživanja o trenutnom radnom statusu i zanimanju. Istraživanje Eurobarometra pritom je razlikovalo tri skupine ispitanika prema radnom statusu (samozaposleni,

5 Izvorna skala u upitniku sadržavala je osam čestica. Posljednja čestica, posjedovanje nekretnine koja se još otplaćuje (na kredit), izbačena je iz analize zbog negativnih koeficijenata korelacije s drugim česticama. 
zaposleni i izvan radnog odnosa) te osamnaest različitih skupina zanimanja (npr. poljoprivrednik, vlasnik tvrtke, zaposleni stručnjak). Za potrebe daljnjih analiza ispitanici su podijeljeni u pet skupina prema trenutnom socioprofesionalnom statusu: 1) niži socioprofesionalni status (poljoprivrednici, kvalificirani fizički radnici, nekvalificirani fizički radnici); 2) srednji socioprofesionalni status (uredski radnici, radnici u uslužnim djelatnostima, trgovački putnici, sitni vlasnici i obrtnici); 3) viši socioprofesionalni status (zaposleni stručnjaci, viši menadžment, srednji menadžment, vlasnici većih tvrtki); 4) izvan radnog odnosa (nezaposleni, kućanice) i 5) umirovljenici. Distribucija socioprofesionalnog statusa pokazuje da najveći udio čine ispitanici bez plaćenog zaposlenja (28,3\%). Među ispitanicima koji su u vrijeme prikupljanja podataka bili u radnom odnosu $(n=357)$ najviše je onih srednjeg socioprofesionalnog statusa (42,3\%), a najmanje onih višeg statusa $(25,8 \%)$.

\section{Razina obrazovanja}

S obzirom na to da je u Eurobarometrovom istraživanju, radi usporedivosti rezultata, korišteno pitanje: „Koliko vam je bilo godina kad ste završili s redovnim obrazovanjem?" kao indikator završenog tercijarnog obrazovanja, u ovom se radu uzima odgovor „20 godina i više“, pri čemu se pretpostavlja da je riječ o visokoobrazovanim ispitanicima.

\section{Obrada podataka}

Kako bi se ispitalo u kojoj su mjeri razlike u kulturnoj potrošnji povezane sa sociodemografskim i socioekonomskim indikatorima te s veličinom naselja i regijom stanovanja, korištene su hijerarhijske regresijske analize. Pritom su indeksi kulturne potrošnje predstavljali kriterijske varijable, dok su kao prediktorske varijable korišteni sociodemografski i socioekonomski indikatori te veličina naselja i regija stanovanja. Skup prediktorskih varijabli u regresijskim analizama uključivao je sljedeće varijable: spol, dob, obrazovanje, indeks posjedovanja materijalnih dobara, samoprocjena socioekonomskog statusa, socioprofesionalni status, veličina naselja i regija stanovanja. Pritom valja naglasiti da su u prvom koraku uključene sociodemografske varijable spola, dobi, obrazovanja te indikatori socioekonomskog položaja (indeks posjedovanja materijalnih dobara, samoprocjena socioekonomskog statusa, socioprofesionalni status), dok su u drugom koraku uključene varijable veličina naselja i regija stanovanja.

Varijable spola, dobi, obrazovanja, samoprocijenjenog društvenog statusa, socioprofesionalnog statusa, veličine naselja i regije stanovanja prvo su rekodirane kao dummy varijable i potom korištene u regresijskim analizama. Za varijablu spola referentna je kategorija bila „ženski spol“, za varijablu dobi referentna je kategorija bila dob od 25 do 39 godina, kod obrazovanja srednjoškolsko obrazovanje (tj. 16 - 19 godina u vrijeme završetka redovnog obrazovanja). Za samoprocijenjeni društveni status i socioprofesionalni status referentne su kategorije bile „srednji status“ u odnosu na ostale. Za veličinu naselja referentna kategorija je bila „od 10.001 do 100.000“, dok je za regiju stanovanja kao referentna kategorija uzeta „Sjeverna Hrvatska“. 


\section{Rezultati}

\subsection{Hijerarhijska regresijska analiza}

Tablica 4.

Sociodemografski i socioekonomski indikatori, veličina naselja i regija stanovanja kao korelati javne kulturne potrošnje

\begin{tabular}{|c|c|c|c|c|}
\hline & & $\beta_{1}$ & $\boldsymbol{\beta}_{2}$ & $\mathbf{r}$ \\
\hline spol (ženski) & & $0,107^{* *}$ & $0,101^{* *}$ & 0,090 \\
\hline \multirow[t]{4}{*}{ dob } & $25-39$ (ref.) & & & \\
\hline & $15-24$ & 0,024 & 0,019 & 0,137 \\
\hline & $40-54$ & $-0,048$ & $-0,054$ & $-0,067$ \\
\hline & 55 i više & $-0,010$ & $-0,045$ & $-0,129$ \\
\hline \multirow[t]{4}{*}{ obrazovanje } & 16 - 19 godina (ref.) & & & \\
\hline & do 15 godina & $-0,082$ & $-0,037$ & $-0,211$ \\
\hline & školuje se ili studira & $0,124^{*}$ & $0,106^{*}$ & 0,204 \\
\hline & 20 i više godina & $0,211^{* *}$ & $0,152^{* * *}$ & 0,319 \\
\hline \multirow[t]{3}{*}{ društveni status (samoprocjena) } & srednji (ref.) & & & \\
\hline & niži & $-0,042$ & $-0,066^{*}$ & $-0,191$ \\
\hline & viši & $0,090^{* * *}$ & $0,108^{* *}$ & 0,207 \\
\hline \multirow[t]{5}{*}{ socioprofesionalni status } & srednji (ref.) & & & \\
\hline & niži & $-0,136^{* *}$ & $-0,104^{* *}$ & $-0,152$ \\
\hline & viši & $0,077^{*}$ & $0,082^{*}$ & 0,285 \\
\hline & umirovljenici & $-0,122^{* *}$ & $-0,094^{*}$ & $-0,120$ \\
\hline & ostali bez plaćenog zaposlenja & $-0,176^{* * *}$ & $-0,116^{* *}$ & $-0,216$ \\
\hline indeks posjedovanja materijalnih dobara & & $0,117^{* *}$ & $0,097^{* * *}$ & 0,238 \\
\hline \multicolumn{5}{|l|}{$\mathbf{R}^{2}=0,277 * *$} \\
\hline \multirow[t]{4}{*}{ veličina naselja } & $10.001-100.000$ (ref.) & & & \\
\hline & do 2000 & & $-0,123^{* *}$ & $-0,252$ \\
\hline & $2001-10.000$ & & $-0,012$ & $-0,032$ \\
\hline & više od 100.000 & & 0,044 & 0,286 \\
\hline \multirow[t]{6}{*}{ regija stanovanja } & Sjeverna Hrvatska (ref.) & & & \\
\hline & Zagreb i okolica & & $0,141^{* *}$ & 0,259 \\
\hline & Slavonija & & $-0,114^{* *}$ & $-0,223$ \\
\hline & Lika i Banovina & & $-0,029$ & $-0,076$ \\
\hline & Istra, Rijeka i Gorski kotar & & $0,088^{*}$ & 0,104 \\
\hline & Dalmacija & & 0,047 & 0,006 \\
\hline$R^{2}=0,350 \Delta R^{2}=0,073$ & & & & \\
\hline
\end{tabular}

Napomene: $\beta 1=$ standardizirani parcijalni regresijski koeficijent $\mathrm{u}$ prvom modelu, $\beta 2=$ standardizirani parcijalni regresijski koeficijent u završnom modelu; $r$ = koeficijent korelacije; $\mathrm{R} 2=$ koeficijent multiple determinacije; $\Delta \mathrm{R} 2=$ promjena koeficijenta multiple determinacije. 
Iz regresijskog modela (tablica 4.) koji prikazuje prediktore javne kulturne potrošnje vidljivo je da je skup sociodemografskih i socioekonomskih prediktora u prvom koraku najviše prediktivan za vrijednost indeksa javne kulturne potrošnje $\left(R^{2}=0,277\right)$. Najveće beta-pondere u prvom modelu ima dob u kojoj je završeno redovno školovanje (20 i više godina: beta $=0,211, \mathrm{p}<0,001$ ), socioprofesionalni status (bez plaćenog zaposlenja: beta $=-0,176, \mathrm{p}<0,001 ;$ niži socioprofesionalni status: beta $=-0,136$, $\mathrm{p}<0,001)$ te indeks posjedovanja materijalnih dobara kao pokazatelj ekonomskog kapitala (beta $=0,117, \mathrm{p}<0,001$ ). Od ostalih prediktora u tom modelu statistički značajnima su se pokazali i spol te procijenjeni status u društvu, dok se dob ispitanika nije pokazala statistički značajnim prediktorom. Dodavanjem veličine naselja i regije stanovanja u drugom koraku povećan je udjel objašnjene varijance za 7,3\%, dok je prediktivna vrijednost pojedinih indikatora iz prvog modela nešto manja, ali još uvijek statistički značajna. Iz modela je vidljivo da najniže vrijednosti indeksa javne kulturne potrošnje imaju ispitanici koji žive u naseljima do 2000 stanovnika. Više vrijednosti indeksa imaju i stanovnici Zagreba i okolice $(r=0,259, \mathrm{p}<0,001)$, dok najnižu vrijednost indeksa pritom imaju stanovnici Slavonije (beta $=-0,114, \mathrm{p}$ $<0,001)$. Prema tome može se zaključiti da veću vrijednost indeksa javne kulturne potrošnje imaju žene, visokoobrazovani ispitanici, oni većeg socioprofesionalnog i socioekonomskog statusa, koji žive u najvećim hrvatskim gradovima.

Iz tablice 5., koja predstavlja prediktore privatne kulturne potrošnje, vidljivo je da skup socioekonomskih i sociodemografskih indikatora iz prvog koraka objašnjava $25 \%$ varijance. Najveću vrijednost beta-pondera pritom ima socioprofesionalni status (bez plaćenog zaposlenja: beta $=-0,215, \mathrm{p}<0,001)$, ženski spol (beta $=0,214, \mathrm{p}<$ $0,001)$ te visoko obrazovanje, odnosno dob u kojoj je završeno redovno školovanje (20 i više godina: beta $=0,206, \mathrm{p}<0,001$; školuju se: beta $=0,197, \mathrm{p}<0,001)$. Vrijednost indeksa privatne kulturne potrošnje pozitivno je povezana i s indeksom posjedovanja materijalnih dobara, a zanimljivo je da nešto nižu vrijednost postiže najmlađa dobna skupina. Dodavanjem veličine naselja i regije stanovanja u drugom koraku objašnjeno je dodatnih 5,8\% varijance. Iz modela je vidljivo da više vrijednosti indeksa privatne kulturne potrošnje imaju ispitanici iz Zagreba i okolice u odnosu na sve ostale regije. Uočljiva je i negativna korelacija s veličinom naselja do 2000 stanovnika. Prema tome može se zaključiti da su kulturne prakse koje se u radu razmatraju kao sastavnice privatne kulturne potrošnje, kao što je čitanje knjiga, raširenije među ženama, visokoobrazovanim osobama višeg socioprofesionalnog statusa te onima koji se trenutno školuju i koji žive u većim urbanim središtima. Za razliku od javne kulturne potrošnje, u ovom se modelu samoprocijenjeni društveni status nije pokazao statistički značajnim. 
Tablica 5.

Sociodemografski i socioekonomski indikatori, veličina naselja i regija stanovanja kao korelati privatne kulturne potrošnje

\begin{tabular}{|c|c|c|c|c|}
\hline & & $\beta_{1}$ & $\beta_{2}$ & $\mathrm{r}$ \\
\hline spol (ženski) & & $0,214^{* * *}$ & $0,209^{* * *}$ & 0,197 \\
\hline \multirow[t]{4}{*}{ dob } & $25-39$ (referentno) & & & \\
\hline & $15-24$ & $-0,093$ & $-0,100^{*}$ & 0,036 \\
\hline & $40-54$ & 0,012 & 0,002 & $-0,018$ \\
\hline & 55 i više & 0,061 & 0,031 & $-0,030$ \\
\hline \multirow[t]{4}{*}{ obrazovanje } & $16-19$ godina (ref.) & & & \\
\hline & do 15 godina & $-0,089^{*}$ & $-0,051$ & $-0,167$ \\
\hline & školuje se ili studira & $0,197^{* *}$ & $0,182^{* *}$ & 0,166 \\
\hline & 20 i više godina (ref.) & $0,206^{* *}$ & $0,161^{\text {*** }}$ & 0,294 \\
\hline društveni status & srednji (ref.) & & & \\
\hline \multirow[t]{2}{*}{ (samoprocjena) } & niži & 0,037 & 0,020 & $-0,072$ \\
\hline & viši & 0,010 & 0,021 & 0,084 \\
\hline socioprofesionalni & srednji (ref.) & & & \\
\hline \multirow[t]{4}{*}{ status } & niži & $-0,144^{* *}$ & $-0,115^{* * *}$ & $-0,154$ \\
\hline & viši & 0,020 & 0,017 & 0,209 \\
\hline & umirovljenici & $-0,096^{*}$ & $-0,083$ & $-0,019$ \\
\hline & bez plaćenog zaposlenja & $-0,215^{* *}$ & $-0,169^{* *}$ & $-0,238$ \\
\hline indeks posjedovanja materijalnih dobara & & $0,136^{* * *}$ & $0,115^{* * *}$ & 0,208 \\
\hline \multicolumn{5}{|l|}{$\mathrm{R}^{2}=0,251^{* *}$} \\
\hline \multirow[t]{4}{*}{ veličina naselja } & $10.001-100.000$ (ref) & & & \\
\hline & do 2000 & & $-0,123^{* *}$ & $-0,252$ \\
\hline & $2001-10.000$ & & $-0,001$ & $-0,034$ \\
\hline & više od 100.000 & & 0,030 & 0,274 \\
\hline \multirow[t]{6}{*}{ regija stanovanja } & Sjeverna Hrvatska (ref.) & & & \\
\hline & Zagreb i okolica & & $0,154^{* *}$ & 0,276 \\
\hline & Slavonija & & $-0,078$ & $-0,199$ \\
\hline & Lika i Banovina & & 0,034 & $-0,011$ \\
\hline & Istra, Rijeka i Gorski kotar & & 0,044 & 0,045 \\
\hline & Dalmacija & & 0,001 & $-0,032$ \\
\hline $\mathrm{R}^{2}=0,309 * * \Delta \mathrm{R}^{2}=0,058$ & & & & \\
\hline
\end{tabular}

Napomene: $\beta 1$ = standardizirani parcijalni regresijski koeficijent u prvom modelu, $\beta 2=$ standardizirani parcijalni regresijski koeficijent u završnom modelu; r = koeficijent korelacije; R2 = koeficijent multiple determinacije; $\Delta \mathrm{R} 2=$ promjena koeficijenta multiple determinacije.

\subsection{Regionalna distribucija kulturne potrošnje}

Regionalna distribucija kulturne potrošnje ukazuje na razmjerno pravilan raspored rangiranja regija u Hrvatskoj. U tablici 6. prikazana je kulturna potrošnja prema indeksima javne i privatne potrošnje za sve regije i državni prosjek. 
Tablica 6.

Kulturna potrošnja prema indeksima javne i privatne kulturne potrošnje za Republiku Hrvatsku i regije

\begin{tabular}{|l|c|c|c|c|c|c|c|}
\hline & $\begin{array}{c}\text { Zagreb i } \\
\text { okolica }\end{array}$ & $\begin{array}{c}\text { Sjeverna } \\
\text { Hrvatska }\end{array}$ & Slavonija & $\begin{array}{c}\text { Lika i } \\
\text { Banovina }\end{array}$ & $\begin{array}{c}\text { Rijeka i } \\
\text { Gorski } \\
\text { kotar }\end{array}$ & Dalmacija & $\begin{array}{c}\text { Republika } \\
\text { Hrvatska }\end{array}$ \\
\hline $\begin{array}{l}\text { Indeks } \\
\text { javne } \\
\text { kulturne } \\
\text { potrošnje }\end{array}$ & 10,3 & 7,9 & 7,0 & 7,9 & 9,8 & 8,8 & 9,0 \\
\hline $\begin{array}{l}\text { Indeks } \\
\text { privatne } \\
\text { kulturne } \\
\text { potrošnje }\end{array}$ & 8,0 & 5,9 & 5,4 & 6,5 & 7,0 & 6,4 & 6,6 \\
\hline
\end{tabular}

Zagreb i okolica te Rijeka i Gorski kotar jedine su regije s iznadprosječnim vrijednostima na obama indeksima, dok je Slavonija postigla najslabije vrijednosti. Primorska Hrvatska pokazuje više rezultate od kontinentalne jer osim Zagreba i okolice sve ostale kontinentalne regije bilježe niske rezultate na obama indeksima.

$\mathrm{Na}$ slici 2. prikazana je regionalna vrijednosti distribucija indeksa javne kulturne potrošnje.

Slika 2.

Regionalna distribucija vrijednosti indeksa javne kulturne potrošnje

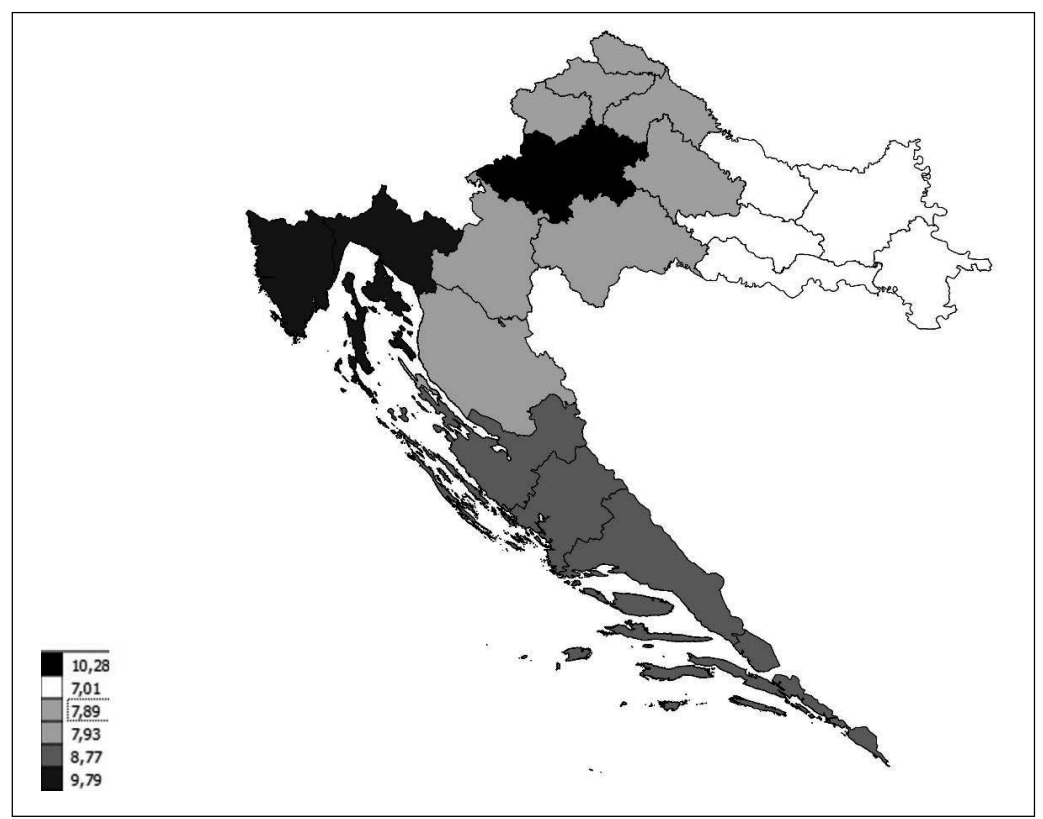

Na slici 3. prikazane su vrijednosti indeksa privatne kulturne potrošnje. Vidlijivo je kako je kod indeksa privatne kulturne potrošnje promjena iskazana samo kod Dalmacije, koja je rangirana niže nego kod indeksa javne kulturne potrošnje, dok su ostale regije zadržale mjesto u poretku. 
Slika 3.

Vrijednosti indeksa privatne kulturne potrošnje

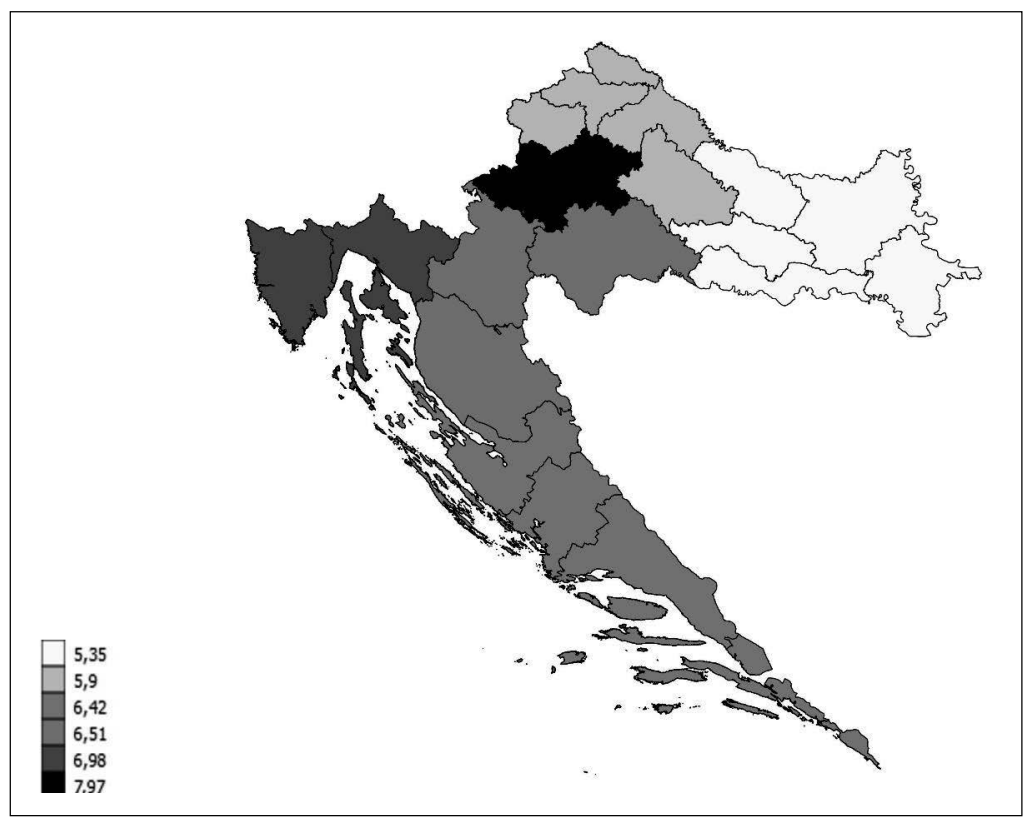

Geografska distribucija kulturne potrošnje pokazuje kako Zagreb i okolica te primorski dijelovi Hrvatske pokazuju veću kulturnu potrošnju, dok je kontinentalna Hrvatska, a pogotovo Slavonija, koja zauzima posljednje mjesto na obama indeksima, konzistentno slabija.

Premda spomenuti rezultati zahtijevaju pomniju statističku analizu radi potvrde, vidljivo je kako je ukupna razvijenost povezana s kulturnom potrošnjom. Grad Zagreb, koji ima najviši rezultat na svim indeksima kulturne potrošnje, ujedno je i najrazvijenija hrvatska županija prema Uredbi o indeksu razvijenosti, s 186\% državnog prosjeka (MRRFEU, 2013.) te ima najveće prihode po stanovniku, dok je Zagrebačka županija četvrta u Hrvatskoj. Prema istim pokazateljima slijede ga Istarska i Primorsko-goranska županija, koje čine drugu teritorijalnu cjelinu u ovome prikazu. Sve županije u Dalmaciji nalaze se u drugoj ili trećoj kategoriji prema indeksu razvijenosti i ona je sumarno treća najrazvijenija regija u Hrvatskoj, a ujedno i treća prema indeksima kulturne potrošnje. S druge strane, pet od šest županija (s izuzetkom Osječko-baranjske) koje sačinjavaju Slavoniju nalazi se na samome dnu po vrijednosti indeksa razvijenosti. Jedina razlika između indeksa kulturne potrošnje i indeksa razvijenosti primjećuje se kod Sjeverne Hrvatske te Like i Banovine, pri čemu je kulturna potrošnja izraženija u potonjoj, iako je sjeverni dio zemlje razvijeniji.

Kako je indeks razvijenosti kompozitni indeks koji uzima u obzir različite ekonomske, obrazovne i demografske parametre, može se zaključiti kako je kulturna potrošnja snažno vezana uz ukupnu razvijenost nekog prostora, što ukazuje na važnost materijalne baze njezine održivosti. Prostori u kojima živi stanovništvo s 
višim prihodima, koje je zaposleno i obrazovano vjerojatnije će imati veću kulturnu potrošnju.

Ekonomski parametri relevantni su i kod ulaganja u kulturu pa se regionalne razlike očituju i reproduciraju i u tome aspektu. Naime, kada se razmotri godišnji proračunski iznos koji se regionalno izdvaja za kulturu (tablica 7.), i ovdje su zagrebačka regija te Istra, Rijeka i Gorski kotar jedine regije iznad nacionalnog prosjeka, Dalmacija je na trećem mjestu s vrijednostima bliskim prosjeku koji iznosi 5.7 tisuća kuna po stanovniku, dok u kulturu najmanje ulažu županije u Slavoniji.

Tablica 7.

Godišnja proračunska sredstva za kulturu po stanovniku, u tisućama kuna

\begin{tabular}{|l|c|c|c|c|c|c|c|}
\hline & $\begin{array}{c}\text { Zagreb i } \\
\text { okolica }\end{array}$ & $\begin{array}{c}\text { Sjeverna } \\
\text { Hrvatska }\end{array}$ & Slavonija & $\begin{array}{c}\text { Lika i } \\
\text { Banovina }\end{array}$ & $\begin{array}{c}\text { Istra, } \\
\text { Rijeka i } \\
\text { Gorski } \\
\text { kotar }\end{array}$ & Dalmacija & $\begin{array}{c}\text { Republika } \\
\text { Hrvatska }\end{array}$ \\
\hline $\begin{array}{l}\text { Godišnja } \\
\text { proračunska } \\
\text { sredstva za } \\
\text { kulturu po } \\
\text { stanovniku }\end{array}$ & 8,3 & 3,6 & 3,5 & 4,4 & 7,3 & 5,4 & 5,7 \\
\hline
\end{tabular}

Izvor: Statistički ljetopis Republike Hrvatske, 2015., str. 554.

Također, može se pretpostaviti da su regionalne razlike u kulturnoj potrošnji dijelom posljedica kulturne centralizacije, odnosno koncentracije kulturne infrastrukture u Zagrebu te u nekoliko većih gradova (Šakaja, 1999.; Dragojević, 2006.; Primorac, 2008.). Kulturna centralizacija vidljiva je i u koncentraciji kulturnih i kreativnih industrija u glavnom gradu (Primorac, 2008.), u raspodjeli javnih financija u kulturi te u koncentraciji umjetničkih akademija i drugih obrazovnih ustanova u području umjetnosti i kreativnih industrija (npr. arhitektura, dizajn). Stanovništvo koje živi izvan većih urbanih središta te u regijama sa slabije razvijenom kulturnom infrastrukturom teže će zadovoljavati svoje kulturne potrebe, što može objasniti niske vrijednosti indeksa kulturne potrošnje, osobito one koja se iskazuje kroz posjećivanje javnih kulturnih sadržaja za koje je potrebna određena razina razvijenosti kulturne infrastrukture.

\section{Rasprava i zaključak}

Primarna intencija rada bila je ispitati u kojoj su mjeri razlike u kulturnoj potrošnji povezane $s$ različitim sociodemografskim i socioekonomskim indikatorima te $s$ veličinom naselja i regijom stanovanja. Analiza podataka prikupljenih istraživanjem Eurobarometra potvrdila je kako postoji statistički značajna povezanost između indeksa kulturne potrošnje s više indikatora socioekonomskog statusa, višom razinom obrazovanja te s rezidencijalnim statusom.

Ponajprije, prema rezultatima provedenih regresijskih analiza, pokazuje se da je viša razina kulturne potrošnje statistički značajno povezana s obrazovanjem, što vrijedi 
za oba indeksa kulturne potrošnje. Ti su rezultati u skladu s rezultatima drugih istraživanja koja su provedena u Hrvatskoj i zemljama bivše Jugoslavije, a koja pokazuju da je sudjelovanje u visokoj kulturi značajno povezano s razinom obrazovanja (Tonković i sur., 2014.; Cvetičanin, 2007.; Cvetičanin, Nedeljković i Krstić, 2012.; Spasić, 2013.). Premda se više razine obrazovanja uobičajeno povezuju sa sudjelovanjem u visokoj kulturi, rezultati pojedinih komparativnih istraživanja sugeriraju da su razlike u kulturnoj potrošnji s obzirom na obrazovno postignuće izraženije u postsocijalističkim europskim društvima u usporedbi s društvima zapadnog kapitalizma (Domański, 2000.; Gerhards i sur., 2013.; van Hek i Kraaykamp, 2013.), što se može tumačiti kao posljedica specifičnih strategija distinkcije u razmjerno egalitarnim društvima, u kojima imovinski status nije mogao biti primarni označitelj klasnog položaja i s njim povezanim životnim stilom, zbog čega je tu ulogu imalo visoko obrazovanje.

Kada je riječ o povezanosti kulturne potrošnje s društvenim i socioprofesionalnim statusom, rezultati analize upućuju na povezanost, premda ona nije tako izražena kao kod obrazovanja. Pritom je vidljivo kako ispitanici nižeg socioprofesionalnog položaja (npr. manualni radnici) imaju niže vrijednosti obaju indeksa, što je sukladno pretpostavkama Bourdieuove teorije homologije. S druge strane, zanimljivo je da se viši socioprofesionalni položaji (npr. menadžeri) povezuju s višim vrijednostima indeksa javne kulturne potrošnje, ali ne i indeksa privatne kulturne potrošnje. Premda objašnjenje tog nalaza zahtijeva daljnja istraživanja, može se pretpostaviti da osobama višeg socioprofesionalnog položaja češće posjećivanje kulturnih sadržaja predstavlja statusni simbol i označitelj životnog stila. Drugi korišteni pokazatelj društvenog statusa, koji se temelji na subjektivnoj procjeni ispitanika, pokazuje se relevantnim samo kod javne kulturne potrošnje, pri čemu smjer povezanosti ostaje isti. Kako upitnik Eurobarometra nije sadržavao pitanje o visini prihoda kao izravnom pokazatelju ekonomskog kapitala, kao približni pokazatelj korišten je indeks posjedovanja materijalnih dobara u kućanstvu. Pogled na dobivene rezultate upućuje na zaključak o postojanju povezanosti između ekonomskog kapitala i razine sudjelovanja u kulturnoj potrošnji. Ipak, pomniji uvid u tu problematiku zahtijevao bi preciznije indikatore imovinskog statusa ispitanika.

Premda bi se zbog količine slobodnog vremena i socijalizacijske uloge kulturne participacije mogle očekivati više vrijednosti indeksa kod mlađih dobnih skupina, dob ispitanika nije se pokazala statistički značajnim prediktorom javne kulturne potrošnje, dok je kod privatne utvrđena niska, ali negativna povezanost s najmlađom dobnom skupinom. Uzevši u obzir da su za potrebe ovog rada iz uzorka izostavljeni ispitanici stariji od 65 godina, a za koje se mogu pretpostaviti niske vrijednosti indeksa kulturne potrošnje, osobito javne, izostanak dobnih razlika u učestalosti posjećivanja i konzumacije različitih kulturnih sadržaja mogao bi se objasniti relativnom stabilnošću kulturnih obrazaca i ukusa koji se stječu za vrijeme socijalizacije. Niže vrijednosti indeksa privatne kulturne potrošnje u najmlađoj skupini ispitanika mogu se tumačiti kao posljedica drugačijih kulturnih obrazaca i praksi kod mlađe populacije. Kao prvo, može se pretpostaviti da mlađe dobne skupine svoje kulturne potrebe dijelom zadovoljavaju u digitalnom prostoru. Osim toga valja primijetiti kako upitnik Eurobarometra pretežno obuhvaća kulturne sadržaje koji se ubrajaju u visoku kulturu, a koje redovito konzumira samo manji dio mladih. 
Iz dobivenih rezultata može se primijetiti kako žene više participiraju u kulturnoj potrošnji, a osobito u kulturnim praksama koje se u radu razmatraju unutar privatnog obrasca, kao što je čitanje knjiga. Premda se ti rezultati mogu usporediti s rezultatima drugih sličnih istraživanja, prema kojima žene općenito više participiraju u praksama koje se povezuju s visokom kulturom te, u usporedbi s muškarcima, više čitaju (Domański, 2000.; Katz-Gerro, 2006.; Katz-Gerro i Sullivan, 2010.), njihova interpretacija i kontekstualizacija traži dodatna pojašnjenja. Naime, kao što primjećuje Katz-Gerro (2006.), važno je uočiti da i među ženama postoje razlike u količini raspoloživog slobodnog vremena i kulturnim obrascima s obzirom na obrazovanje, društveno porijeklo, veličinu obitelji i druge karakteristike. Primjerice, veća participacija žena u visokoj kulturi može biti posljedica većeg angažmana žena u socijalizaciji djece, koja uključuje i brigu o stjecanju kulturnog kapitala. U svrhu preciznijeg uvida u interakcije roda s drugim prediktorima kulturne potrošnje potrebna su daljnja istraživanja uz upotrebu razrađenijih mjernih instrumenata.

Nadalje, oba obrasca kulturne potrošnje značajno su povezana s indikatorima rezidencijalnog statusa, odnosno veličinom naselja i regijom stanovanja, i to uz kontrolu drugih sociodemografskih i socioekonomskih indikatora. Drugim riječima, rezultati pokazuju da je razvijenost i urbaniziranost prostora važan preduvjet za redovito sudjelovanje u kulturnoj potrošnji. Premda zbog ograničenja mjernog instrumenta nije moguće zaključivati o suptilnijim razlikama u kulturnoj potrošnji s obzirom na rezidencijalni status, rezultati istraživanja sukladni su prethodnim istraživanjima u Hrvatskoj i šire, a koji upućuju na razlike između urbanog i ruralnog kada je riječ o obrascima kulturne potrošnje i životnog stila, odnosno na povezanost kulture s geografskim i društvenim teritorijem. Istodobno, niske razine kulturne participacije u ruralnim i slabije razvijenim područjima mogu predstavljati oblik socijalne isključenosti, koja se u ovom slučaju manifestira u vidu smanjene dostupnosti kulturnih sadržaja i mogućnosti za aktivniju participaciju u kulturi. Uviđajući važnost tog problema, pojedine su lokalne i nacionalne vlade predlagale eksplicitne kulturne politike s ciljem povećanja dostupnosti kulturnih sadržaja i jačanja participacije širih slojeva stanovništva u kulturnom životu (Bennett i Silva, 2006.). U prilog takvim politikama govore i nalazi van Hek i Kraaykamp (2013.), koji demonstriraju povezanost između razine ulaganja u kulturnu infrastrukturu i razine sudjelovanja širih slojeva stanovništva u potrošnji visoke kulture. Premda je razina kulturne participacije u Hrvatskoj uvelike uvjetovana regionalnim razlikama u stupnju razvijenosti, za sada izostaju konkretne mjere javnih politika koje bi nastojale odgovoriti na taj problem.

Naposljetku, valja napomenuti kako je pri analizi podataka dobivenih istraživanjem Eurobarometra potrebno uzeti u obzir metodološke nedostatke samog istraživanja. Prije svega, operacionalizacija kulturne potrošnje sa samo devet različitih kulturnih sadržaja ne omogućuje dobivanje preciznijeg uvida u kulturne navike ispitanika. Osim toga, zbog ograničenja samog mjernog instrumenta otežano je i povezivanje rezultata istraživanja s teorijskim pristupima koji se bave razmatranjem odnosa između društvene stratifikacije i kulturne potrošnje. S obzirom na relevantnost ovog predmetnog područja, ali i na nedostatak sustavnih istraživanja ove tematike u Hrvatskoj, poželjno je da buduća istraživanja provedena na nacionalnom reprezentativnom uzorku obuhvate više tipova kulturnih sadržaja, što bi omogućilo utvrđivanje 
distinkcija između različitih tipova ukusa i njihovo preciznije povezivanje s društvenim razlikama.

\section{Literatura}

1. Beck, U. (1992). Risk Society. Towards a New Modernity. London/Newbury Park/ New Delhi: Sage Publications.

2. Bennett, T. and Silva, E. (2006). Cultural Capital and Inequality - Policy Issues and Contexts. Cultural Trends, 15 (2-3): 87-106.

3. Bourdieu, P. (2011 [1979]). Distinkcija: društvena kritika suđenja. Zagreb: Antibarbarus.

4. Bukodi, E. (2010). Social stratification and cultural participation in Hungary: a post-communist pattern of consumption, in: Chan, T. W. (Ed.). Social status and cultural consumption. Cambridge: Cambridge University Press, 139-168.

5. Burić, I. (2010). Nacija zaduženih. Od komunističkog pakla do potrošačkog kapitalizma. Zagreb: Jesenski i Turk.

6. Cavallaro, C. (2010). Regional Geography, in: Mangiameli, S. (Ed.). Italian Regionalism: Between Unitary Traditions and Federal Processes. Investigating Italy's Form of State. London: Springer, 81-110.

7. Chan, T. W. (2010). Conclusion, in: Chan, T. W. (Ed.). Social status and cultural consumption. Cambridge: Cambridge University Press, 232-251.

8. Chan, T. W. and Goldthorpe, J. H. (2005). The social stratification of theatre, dance and cinema attendance. Cultural Trends, 14 (3): 193-212.

9. Chan, T. W. and Goldthorpe, J. H. (2006). Social Stratification and Cultural Consumption: Music in England. European Sociological Review, 23 (1): 1-19.

10. Chan, T. W. and Goldthorpe, J. H. (2010). Social status and cultural consumption, in: Chan, T. W. (Ed.). Social status and cultural consumption. Cambridge: Cambridge University Press, 139-168.

11. Coulangeon, P. and Lemel, Y. (2010). Bourdieu's legacy and the class-status debate on cultural consumption: musical consumption in contemporary France. in: Chan, T. W. (Ed.). Social status and cultural consumption. Cambridge: Cambridge University Press, 84-108.

12. Cvetičanin, P. (2007). Kulturne potrebe, navike i ukus građana Srbije i Makedonije. Niš: OGI.

13. Cvetičanin, P.; Nedeljković, J. and Krstić, N. (2012). The Cultural Map of Serbia or Reconstruction of the Field of Cultural Practices in Serbia, in: Cvetičanin, P. (Ed.). Social and Cultural Capital in Serbia. Niš: Center for Empirical Cultural Studies of Southeast Europe.

14. Cvjetičanin, B. and Katunarić, V. (1999). Cultural policy in Croatia. National report. Strasbourg: Concil for Cultural Cooperation, Council of Europe; Ministry of Culture of the Republic of Croatia; Institute for International Relations.

15. Cvjetičanin, B. i Katunarić, V. (2003). Hrvatska u 21. stoljeću: Strategija kulturnog razvitka. Zagreb: Ministarstvo kulture Republike Hrvatske.

16. Čolić, S. (2008). Sociokulturni aspekti potrošnje, potrošačke kulture i društva. Društvena istraživanja, 98 (6): 953-974. 
17. Domański, H. (2000). On the Verge of Convergence. Social Stratification in Eastern Europe. Budapest: Central European University Press.

18. Dragojević, S. (2006). Kulturna politika: europski pristupi i modeli. Doktorska disertacija. Zagreb: Sveučilište u Zagrebu, Fakultet političkih znanosti.

19. European Commission, Brussels (2014). Eurobarometer 79.2. (2013). TNS Opinion, Brussels [producer]. GESIS Data Archive, Cologne. ZA5688 [datoteka s podacima].

20. Eurostat (2013). Special Eurobarometer 399. Cultural access and participation. Dostupno na: (http://ec.europa.eu/public_opinion/archives/ebs/ebs 399 en.pdf).

21. Gerhards, J.; Hans, S. and Mutz, M. (2013). Social Class and Cultural Consumption: The Impact of Modernisation in a ComparativeEuropean Perspective. Comparative Sociology, 12: 160-183.

22. Giddens, A. (1991). Modernity and Self-Identity. Self and Society in the Late Modern Age. Stanford: Stanford University Press.

23. Giddens, A. (1990). The Consequences of Modernity. Cambridge: Polity Press.

24. Hek van, M. and Kraaykamp, G. (2013). Cultural consumption across countries: A multi-level analysis of social inequality in highbrow culture in Europe. Poetics, 41: 323-341.

25. Hromadžić, H. (2008). Konzumerizam. Potreba, životni stil, ideologija. Zagreb: Naklada Jesenski i Turk.

26. Ilišin, V. i Radin, F. (2007). Mladi: problem ili resurs. Zagreb: Institut za društvena istraživanja.

27. Katz-Gerro, T. (2006). Comparative evidence of inequality in cultural preferences: gender, class and family status. Sociological Spectrum, 26: 63-83.

28. Katz-Gerro, T. and Sullivan, O. (2010). Voracious cultural consumption. The intertwining of gender and social status. Time E Society, 19 (2): 193-219.

29. Kraaykamp, G.; van Eijck, K. and Ultee, W. (2010). Status, class and culture in the Netherlands, in: Chan, T. W. (Ed.). Social status and cultural consumption. Cambridge: Cambridge University Press, 169-203.

30. Kraaykamp, G. and Nieuwbeerta, P. (2000). Parental Background and Lifestyle Differentiation in Eastern Europe: Social, Political, and Cultural Intergenerational Transmission in Five Former Socialist Societies. Social Science Research, 29: 92122.

31. Lash, S. (1993). Reflexive modernization: the aesthetic dimension. Theory, Culture E Society, 10 (1): 1-23.

32. López Sintas, J. and García Álvarez, E. (2002). Omnivores show up again. The segmentation of cultural consumers in Spanish social space. European Sociological Review, 18 (3): 353-368.

33. Marcelić, S.; Krolo, K. i Tonković, Ž. (2015). Turbofolk - od zabranjenog voća do mainstreama: istraživanje glazbenog ukusa zadarskih srednjoškolaca. Casca, 4 (1). Dostupno na: (http://www.journal.casca.org.rs/2015/12/30/br4-sadrzaj/).

34. Peterson, R. A. (1992). Understanding audience segmentation: from elite and mass to omnivore and univore. Poetics, 21 (4): 243-258.

35. Peterson, R. A. and Kern, R. M. (1996). Changing highbrow taste: from snob to omnivore. American Sociological Review, 61: 900-907. 
36. Peterson, R. A. and Simkus, A. (1992). How musical tastes mark occupational status groups, in: Lamont, M. and Fournier, M. (Eds.). Cultivating differences: Symbolic boundaries and the making of inequality. Chicago: University of Chicago Press, 152-186.

37. Primorac, J.; Obuljen Koržinek, N. and Uzelac, A. (2015). Access to culture in Croatian cultural policy: moving towards explicit policies. International Journal of Cultural Policy.

38. Primorac, J. (2008). Razvoj kulturnih/kreativnih industrija u Hrvatskoj - perspektiva kulturnih djelatnika, u: Švob-Đokić, N.; Primorac, J. i Jurlin, K. (Ur.). Kultura zaborava. Industrijalizacija kulturnih djelatnosti. Zagreb: Naklada Jesenski i Turk, Hrvatsko sociološko društvo, 69-117.

39. Shields, R. (Ed.) (1992). Lifestyle Shopping. The Subject of Consumption. London: Routledge.

40. Spasić, I. (2013). Kultura na delu. Društvena transformacija Srbije iz burdijeovske perspektive. Beograd: Fabrika knjiga.

41. Šakaja, L. (1999). Kultura i prostor. Prostorna organizacija kulturnih djelatnosti u Hrvatskoj. Zagreb: Hrvatska sveučilišna naklada.

42. Tonković, Ž.; Krolo, K. i Marcelić, S. (2014). Kulturna potrošnja i glazbene preferencije mladih: razvoj tipologije na primjeru Zadra. Revija za sociologiju, 44 (3): 287-315.

43. Zdravković, Ž. (2014). Medijska dimenzija životnih stilova studenata/ica kao pokazatelj razvojnog potencijala regije. Doktorska disertacija. Zadar: Sveučilište u Zadru. 


\title{
Željka Tonković
}

University of Zadar, Department of Sociology, Croatia

e-mail: ztonkovi@unizd.hr

Sven Marcelić

University of Zadar, Department of Sociology, Croatia

e-mail:smarceli@unizd.hr

Krešimir Krolo

University of Zadar, Department of Sociology, Croatia

e-mail:kkrolo@unizd.hr

\section{Cultural Consumption, Social Inequalities and Regional Differences: Eurobarometer Survey in Croatia in 2013}

\begin{abstract}
The main goal of this article is to establish whether there is a connection between cultural consumption, social inequality and regional differences in Croatia based on data collected from the Eurobarometer survey in 2013. In the first part of the article different theoretical approaches are presented, explaining precise determinants of cultural consumption and taking into account transitional and post-transitional specificities of the Croatian society. Methodological/empirical segment of the article is divided into three steps. Firstly, by using factor analysis, cultural consumption of respondents $(N=787)$ is divided into two main domains, public and private cultural consumption, based on which their aggregate indexes are created. After that, the hierarchial regression analysis is included in order to establish how the socioeconomic status is predictive of different types of cultural consumption. And finally, the cultural consumption index is compared in different regions of Croatia in relation to their development index. The results of the analysis indicate a strong correlation between both indexes of cultural consumption and several indicators of socioeconomic status, education level, gender and residential status. There are significant differences in various Croatian regions; the wider Zagreb metropolitan area, Rijeka and Gorski Kotar are the only regions with above than average cultural consumption index. It follows that cultural consumption is strongly related to the overall development of an area.
\end{abstract}

Key words: cultural consumption, social inequalities, Eurobarometer, Croatia, regional differences, socioeconomic status. 